Archives of Agriculture and Environmental Science

\title{
Evaluation of microbiological quality of dried baim (Mastacembelus armatus) in Bangladesh
}

\author{
Tania Akter ${ }^{1 *}$, Md. Abu Sayeed ${ }^{1}$, Md. Golam Rasul ${ }^{2}$ (D) , Md. Abul Kashem ${ }^{1}$ and Ajit Kumar Paul ${ }^{3}$ \\ ${ }^{1}$ Department of Fisheries Technology and Quality Control, Sylhet Agricultural University, Sylhet-3100, BANGLADESH \\ ${ }^{2}$ Department of Fisheries Technology, Bangabandhu Sheikh Mujibur Rahman Agricultural University, Gazipur-1706, BANGLADESH \\ ${ }^{3}$ Deputy Project Director, Expansion of Aquaculture Technology Services up to Union Level Project (Phase II), Department of \\ Fisheries (DoF), BANGLADESH \\ 'Corresponding author's E-mail: taniaakter1320@gmail.com
}

\section{ARTICLE HISTORY}

Received: 03 November 2018

Accepted: 26 November 2018

\section{Keywords}

Dried baim

Microbiological quality

Pathogenic bacteria

TPC

TFC

\section{ABSTRACT}

A study was performed for five months to assess the microbiological quality of dried Baim (Mastacembelus armatus) in Sylhet region of Bangladesh. A total of 45 dried samples were randomly collected on monthly basis from three different sources of Sylhet region; one from producer (drying yard of Lamagaji) and others from retail market (Bandar Bazar) and control (prepared in laboratory). The mean total plate count (TPC) of dried Baim from producer, retail market and control were observed $6.20 \pm 0.72 \times 10^{5}, 9.64 \pm 1.58 \times 10^{5}$ and $1.61 \pm 1.06 \times 10^{5} \mathrm{cfu} /$ $\mathrm{g}$, respectively, whereas, average total fungal count (TFC) were estimated $3.77 \pm 0.81 \times 10^{3}$, $4.65 \pm 1.08 \times 10^{3}$ and $1.78 \pm 0.64 \times 10^{3} \mathrm{cfu} / \mathrm{g}$, respectively. TPC and TFC of dried Baim of retail market were found significantly $(P<0.05)$ highest and significantly $(P<0.05)$ lowest in control samples than others. Twenty five samples from each source were analyzed to determine pathogenic E. coli and Salmonella sp. Hundred percent samples of dried Baim of producer and retail market were found contaminated by E. coli whereas; the controlled samples were free of E. coli. Likewise, the dried Baim samples of producer and retail market were contaminated $60 \%$ and $80 \%$ respectively with Salmonella. Dried baim sample from market was $100 \%$, producer sample was $62 \%$ and control sample was $32 \%$ contaminated with fungi. The most common fungus species in samples were Aspergillus fumigatus, Fuserium proliferatum and Rhizopus stolonifer. The overall microbiological quality of control samples was comparatively better than the commercially produced dried Baim in Sylhet region.

(C)2018 Agriculture and Environmental Science Academy

Citation of this article: Akter, T., Sayeed, M.A., Rasul, M.G., Kashem, M.A. and Paul, A.K. (2018). Evaluation of microbiological quality of dried baim (Mastacembelus armatus) in Bangladesh. Archives of Agriculture and Environmental Science, 3(4): 344-353, https://dx.doi.org/10.26832/24566632.2018.030403

\section{INTRODUCTION}

Bangladesh has the world's biggest flooded aquatic wetland after China and India; it is the third largest aquatic biodiversity in Asia. The contribution of the fisheries sector is 3.69 per cent in the Gross Domestic Product (GDP) of the country and $22.60 \%$ to the agricultural GDP (FRSS, 2016). In the FY 2017-2018, Bangladesh earned Tk 4,500 crore by exporting at least 69,000 tonnes of fish and fish products. The greater Sylhet region of Bangladesh together with Moulovibazar, Sunamganj and Habiganj has vast water bodies and is enriched with haor fisheries
(Mazid and Kamal, 2005). During winter season, huge quantities of small fishes are usually harvested from these areas than those of the other seasons.

Drying is a food preservation method that works by lowering water activity from the food, which prevents the growth of microbes (Bala and Mondol, 2001; Bellagha et al., 2002; Duan et al., 2004; Beuchat et al., 2013). Open air sun drying has been practiced from ancient times to preserve food for longer period of time (Rasul et al., 2018; Hasan et al., 2016). The proportion about $20 \%$ of the artisanal catch is being dried by traditional sun drying methods and consumed in the domestic market (Nowsad, 
2007). The quantity of dry fish export would raise by $0.46 \%$ yearly. The total amount would increase by $2.30 \%$ i.e., from 355.30 thousand tones to 363.30 thousand tones during the period from 2010-11 to 2015-16 in Bangladesh (Sen et al., 2015). Though, dried fish is a low cost source of high quality protein to the low income population (Petrus et al., 2013), the consumers now a day are very much concerned about the quality of dried products, particularly chemical contaminants, spoilage and infestation by blow flies. Traditional drying is often undeveloped and good hygiene and sanitation is rarely practiced. Various microorganisms adversely affect to the quality of sun dried fishes. It has been stated that dried food and their ingredients were contaminated by pathogenic and harmful microorganisms like as Escherichia coli 0157:H7 (Deng et al.,1998), and Salmonella sp. (Archer et al., 1998; Beuchat and Mann, 2011). The incidence of Salmonella spp. in various dried fishes directly indicated the maintenance of low as well as poor hygienic condition during dried fish processing (Sultana et al. 2010). Particularly, some pathogenic molds have been found as considerable amount in dried food (Hyun et al., 2018). There are some species of spoilage molds and osmophilic yeasts that can grow at relatively low Aw values from 0.60 to 0.70 (Cousin et al., 2005). The presence of the pathogenic microbial loads in dried fishes is getting importance in the safety and quality aspects of the dried fishes (Patterson and Ranjitha, 2009). So, is very essential to determine the microbiological quality of such processed fishes for guarding consumer's health and hygiene (Lilabati et al., 1999). The information about the microbial load and pathogenic bacteria of dried Baim associated with fungal strain in dried fish products is lacking which drive us to look into it. Detailed microbial qualities make sure that products available to consumers are not only nutritious but also free of potentially harmful microbiota (PHM). So, it is very important to assess microbiological quality and safety of dried fishes in retail trade for protecting health and hygiene of local consumer. The present study thereby aimed and conducted to determine microbiological quality of dried Baim of Sylhet region.

\section{MATERIALS AND METHODS}

\section{Collection of samples}

Dried Baim (Mastacembelus armatus) was selected as sample dried fish which is one of the most available and popular dry fish in Sylhet region of Bangladesh. Sample was collected from three different sources on monthly basis; Lamagaji fish drying yard of Sunamgonj, Banadar Bazar (Retail Market) of Sylhet Sadar and control sample prepared in every month of study period in laboratory of Department of Fisheries Technology and Quality Control, SAU with proper hygienic and sanitation condition. Raw fresh Baim used to prepare control sample were collected from Tilagor fish market, Sylhet Sadar uazilla of Sylhet district. The dried fish was packed into airtight polyethene bags and stored at room temperature for subsequent analysis. Samples were collected as monthly basis from December 2016 to April 2017.
Total plate count (TPC)

Bacterial load was determined using plate count agar (PCA) by spread plate technique. Ten grams of the sample was mixed with 10 fold volume of physiological saline $(0.85 \% \mathrm{NaCl})$ which was serially mixed ten folds. Appropriate dilutions of fish homogenate were spread on plate count agar. Then incubated at $37^{\circ} \mathrm{C}$ for 24 hours and the colonies were counted for total plate count having plates $30-300$ colonies and the count was expressed as $\mathrm{cfu} / \mathrm{g}$ (APHA, 1992).

\section{Total fungal count (TFC)}

Fungal count was conducted out using sabouraud dextrose agar (SDA) to which Chloramphenicol (antibiotics) was mixed. Twenty-five grams of the sample was blended with $225 \mathrm{ml}$ of $0.05 \%$ agar in saline solution $(0.85 \% \mathrm{NaCl})$ and $0.1 \mathrm{ml}$ of the appropriate dilutions of the sample was spread on the surface of the medium. Then incubated at room temperature $\left(28 \pm 1^{\circ} \mathrm{C}\right)$ for 3-5 days and the colonies were counted for total fungal count and the count was expressed as cfu/g (Yamagata, 1992).

\section{Detection of pathogenic bacteria E. coli}

Homogenated dry fish was transferred to LSTB tubes. Then incubated at $37^{\circ} \mathrm{C}$ for 24 hours and observed for growth and gas production. Samples from positive LSTB tubes were transferred to EC broth tubes and incubated at $37^{\circ} \mathrm{C}$ for $24-48$ hours, Samples from positive EC broth was streaked on to eosin methylene blue (EMB) agar plate to sure that the E. coli. Black or dark centered colonies with or without greenish metallic sheen were produced by E. coli. Further biochemical tests (Sugar fermentation test, Indole test, MR test, VP test, TSI slant test and Catalase test) were completed for identification of E. coli (AOAC, 1998).

\section{Salmonella spp.}

In the detection of Salmonella, lactose broth (LB) was used which act as pre-enrichment and tetrathionate broth and seletinecystine broth were used in enrichment. Isolation for Salmonella, xylose lysine deoxycholate (XLD) was used. Further biochemical tests were done for identification of Salmonella (AOAC, 1998). Salmonella exhibited pink colonies with or without black centers (FDA BAM, 2007).

\section{Isolation of fungal organisms}

At first, ten-fold serial dilution of $1 \mathrm{~g}$ of fish with distilled water then $0.1 \mathrm{ml}$ of the dilution was cultured by spread plate technique into Potato dextrose agar (PDA) supplemented with chloramphenicol at $40 \mu \mathrm{g} / \mathrm{ml}$ and Gentamycin at $500 \mu \mathrm{g} / \mathrm{ml}$. Then incubated for 5 to 14 days at room temperature. Pure culture of the different colonies (based on morphology) was obtained by sub-culture of the isolates on potato dextrose agar plates and sabouraud's dextrose agar plates. The fungal isolates were identified to the genus/species level based on macroscopic and microscopic characteristics and all of the isolates obtained from pure cultures. 


\section{Culture of samples}

From the sample an inoculum is prepared and streaked on the SDA media and incubated at room temperature. The different plate media were looked for the fungal growth every day until growth is found after 3 to 4 days of plating. Pure culture was prepared from this initial culture (Rippon, 1998).

\section{Preparation of pure culture}

In order to make a pure culture, spores from initial culture was transferred to media containing petridishes by sterilized inoculating loop to avoid any contamination with other fungus and incubate for 3-4 days at room temperature until the fungal growth is found.

\section{Identification of fungus}

Fungal colony was taken with the help of an inoculating needle on a fresh glass slide containing two drops of lactophenol cotton blue from pure culture. The fungal colony was covered with a cover slip and the slides were examined under the microscope. The fungus was identified on the basis of its cultural and morphological characteristics (Rippon, 1998).

\section{Data analysis}

All data were subjected to statistical analysis using one-way ANOVA including IBM SPSS, Version 20.0. Probabilities of $P<0.05$ were considered significant. Significance differences between means were assessed using the Duncan's multiple range test.

\section{RESULTS AND DISCUSSION}

Quantitative microbiological analysis of dried Baim fish

\section{Total plate count (TPC) of dried Baim fish}

Results of total plate count of dried Baim fishes from three different sources are presented in Table 1. In each month significantly $(P<0.05)$, the highest bacterial load was found in Market source compared to control source. In the month of February and March, no significant differences were observed between bacterial load of Producer and Market source. Similarly, no significant difference was found in the bacterial of Producer and Control source in the month of February. Overall, significantly $(P<0.05)$ the highest and the lowest bacterial count were observed in the month of April and January, respectively.

\section{Total fungal count (TFC) of dried Baim fish}

Results of total fungal count of dried Baim fishes collected from different sources are shown in Table 2. In each month, significantly $(P<0.05)$ the lowest fungal count were estimated in Control source. Significantly the highest fungal count was found in Market source in the month of December, March and April. Whereas, significantly the highest fungal load was observed in Producer source in the month of February and April. However, no significant differences were found between the fungal counts of Producer and Market source in the month of January, February and April. Likewise, no significant differences were found between the fungal counts of Producer and Control source. Overall, significantly $(P<0.05)$ the highest and the lowest fungal counts were observed in the month of March and January, respectively.

Isolation and identification of indicator bacteria (Escherichia coli)

\section{Cultural properties of E. coli}

E. coli is an aerobic and facultative anaerobic bacteria. Optimum temperature for growth was $36-37^{\circ} \mathrm{C}$ where most strains grew over the range of $18-44^{\circ} \mathrm{C}$. E. coli is a Gram negative rod shaped bacteria and it varies from coccoid bipolar shape to long filamentous form. The colonies usually developed to a size of 2-3 $\mathrm{mm}$ on agar media. E. coli. found metallic sheen on the EMB agar, also found rose pink colony on the MacConkey agar and pinkish colony on the Salmonella-Shigella (SS) agar medium (Table 3).

Table 1. Total plate count (cfu/g) (Mean \pm SD) of dried Baim fish from different sources $(n=3)$. Different superscripts in each row represent significant difference $(P<0.05)$.

\begin{tabular}{lccc}
\hline \multirow{2}{*}{ Month } & \multicolumn{3}{c}{ Sample source } \\
\cline { 2 - 4 } & Producer & Market & Control \\
\hline December & $6.70^{\mathrm{b}} \pm 0.40 \times 10^{5}$ & $9.77^{\mathrm{c}} \pm 0.95 \times 10^{5}$ & $1.20^{\mathrm{a}} \pm 0.30 \times 10^{5}$ \\
January & $5.60^{\mathrm{b}} \pm 0.30 \times 10^{5}$ & $8.23^{\mathrm{c}} \pm 0.55 \times 10^{5}$ & $0.93^{\mathrm{a}} \pm 0.25 \times 10^{5}$ \\
February & $6.03^{\mathrm{b}} \pm 0.15 \times 10^{5}$ & $8.90^{\mathrm{c}} \pm 0.90 \times 10^{5}$ & $1.03^{\mathrm{a}} \pm 0.55 \times 10^{5}$ \\
March & $5.55^{\mathrm{b}} \pm 0.55 \times 10^{5}$ & $9.00^{\mathrm{c}} \pm 0.10 \times 10^{5}$ & $1.40^{\mathrm{a}} \pm 0.40 \times 10^{5}$ \\
April & $7.13^{\mathrm{b}} \pm 0.41 \times 10^{5}$ & $12.30^{\mathrm{c}} \pm 0.62 \times 10^{5}$ & $3.50^{\mathrm{a}} \pm 0.70 \times 10^{5}$ \\
\hline
\end{tabular}

Table 2. Total fungal load (cfu/g) (Mean \pm SD) of dried Baim fishes from different sources $(n=3)$. Different superscripts in each row represent significant difference $(P<0.05)$.

\begin{tabular}{lccc}
\hline \multirow{2}{*}{ Month } & \multicolumn{3}{c}{ Sample source } \\
\cline { 2 - 4 } & Producer & Market & Control \\
\hline December & $3.57^{\mathrm{b}} \pm 0.75 \times 10^{3}$ & $5.20^{\mathrm{c}} \pm 1.05 \times 10^{3}$ & $1.40^{\mathrm{a}} \pm 0.40 \times 10^{3}$ \\
January & $4.14^{\mathrm{b}} \pm 0.95 \times 10^{3}$ & $3.50^{\mathrm{b}} \pm 0.70 \times 10^{3}$ & $2.10^{\mathrm{a}} \pm 0.65 \times 10^{3}$ \\
February & $3.07^{\mathrm{b}} \pm 0.20 \times 10^{3}$ & $4.50^{\mathrm{c}} \pm 0.90 \times 10^{3}$ & $1.50^{\mathrm{a}} \pm 0.70 \times 10^{3}$ \\
March & $3.83^{\mathrm{b}} \pm 1.05 \times 10^{3}$ & $5.23^{\mathrm{b}} \pm 1.05 \times 10^{3}$ & $2.30^{\mathrm{a}} \pm 0.65 \times 10^{3}$ \\
April & $4.26^{\mathrm{b}} \pm 0.80 \times 10^{3}$ & $4.83^{\mathrm{c}} \pm 1.30 \times 10^{3}$ & $1.60^{\mathrm{a}} \pm 0.70 \times 10^{3}$ \\
\hline
\end{tabular}


Table 3. Cultural characteristics of isolated E. coli on different media.

\begin{tabular}{lll}
\hline Feature & Appearance & Pictorial view \\
\hline
\end{tabular}

Nutrient broth

Nutrient Agar

Eosin Methylene Blue Agar (EMB)

MacConkey Agar (MC)

Salmonella- Shigella Agar

Gram's staining
Turbidity, cloudiness in the broth, heavy sediment at the bottom of the test tube

Smooth, circular, white to grayish white colonies were found.

Smooth, circular, black color colonies with metallic sheen was produced.

Rose pink lactose fermented colonies were formed.

Slight pinkish colonies

E. coli is a gram negative rod shaped
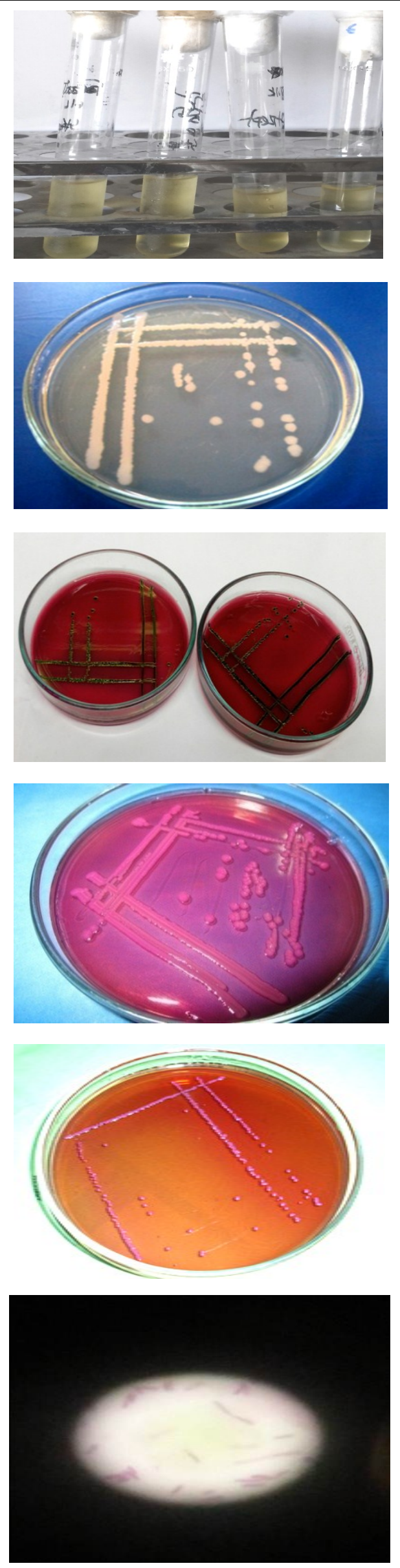
Biochemical tests

All of the E. coli isolates fermented all five basic sugars like dextrose, maltose, lactose, sucrose and mannitol with the production of acid. Acid production was reported by the color change from reddish to yellow and gas production was marked by the presence of gas bubbles in the inverted Durham's tubes. On TSI agar slant, E. coli showed positive result by indicating slant red and butt yellow colored. E. coli gives negative reaction to Voges Proskauer (VP) test and positive reaction to Methyl red test (MR test) which was indicated by stable red color. Escherichia coli produce vigorous gas bubble which was indicative of Catalase positive and negative to VP reaction test (Table 4).
Isolation and identification of pathogenic bacteria, Salmonella

\section{Cultural properties of Salmonella}

Salmonella is Enterobacteriaceace which is gram negative and motile with peritrichous flagella. Salmonella is non spore forming rods and the rods are typically $0.7-1.5 \mu \mathrm{m} \times 2.5 \mu \mathrm{m}$ in size. Salmonella is facultative anaerobic which can grow with or without oxygen. Salmonella show catalase positive and oxidase negative reactions. Salmonella produce turbidity on the NB agar, colorless colony on the MacConkey agar and black centered colony on the Salmonella-Shigella (SS) agar medium (Table 5).

Table 4. Results of different biochemical tests.

\begin{tabular}{lllllllll}
\hline \multirow{2}{*}{ Indole } & MR & VP & Catalase test & TSI Slant & & \multicolumn{3}{c}{ Sugar fermentation test } \\
\cline { 5 - 9 } & & & & Dextrose & Maltose & Mannitol & Lactose \\
\hline$+\mathrm{ve}$ & $+\mathrm{ve}$ & -ve & +ve with gas bubble & yellow & +ve & +ve & +ve & -ve \\
\hline
\end{tabular}

Table 5. Cultural characteristics of Salmonella in different culture media.

$\begin{array}{lll}\text { Media used } & \text { Cultural characteristics } & \text { Pictorial view } \\ \text { Nutrient broth } & \text { Produced turbidity }\end{array}$

Nutrient agar

MacConkey agar

Salmonella agar

Gram`s staining method
Translucent, opaque, smooth, circular colonies

Grow colorless colonies

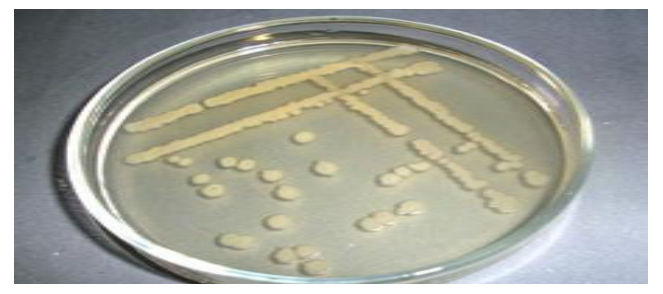

Black centered colonies
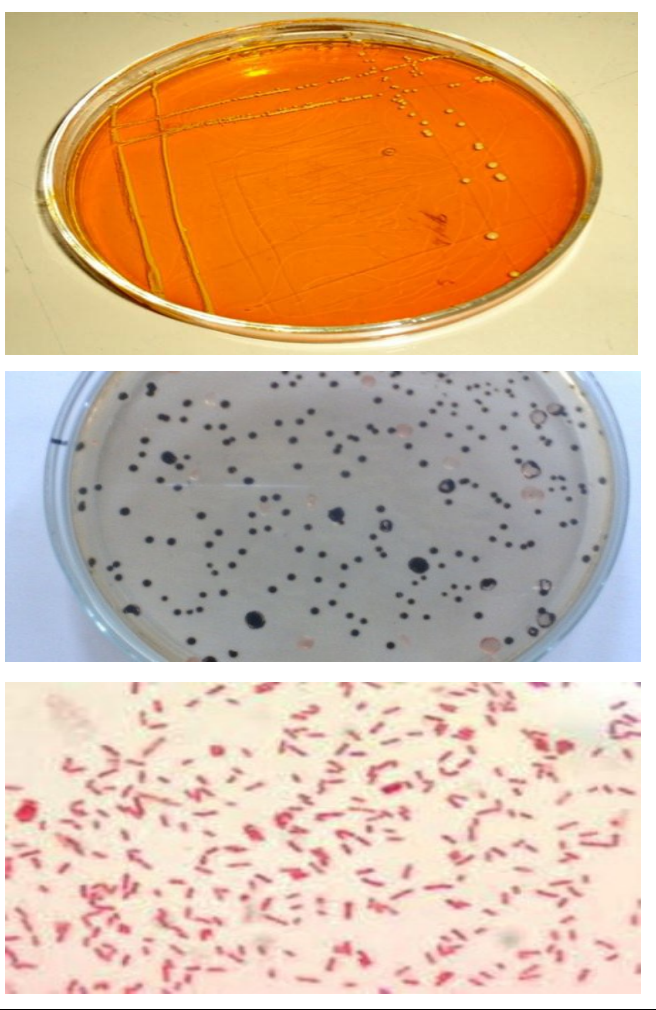
Biochemical tests

All of the Salmonella isolates fermented three sugars dextrose, maltose and mannitol with the production of acid and gas but did not ferment lactose and sucrose. Acid production was noted by the color change from reddish to yellow and gas production was marked by the presence of gas bubbles in the inverted Durham's tubes. On TSI agar slant, Salmonella sp. showed positive result by indicating black colored butt. Salmonella sp. gives positive reaction to Methyl red test (MR test) which was indicated by stable red color and negative reaction to Voges Proskauer (VP) test. Salmonella sp. gives negative reaction to indole test and produce gas bubbles which were indicative of Catalase test positive (Table 6).

Isolation of $E$. coli and Salmonella from dried Baim fishes

In each month, three dried Baim fish samples from each source were analyzed to determine the qualitative microbiological quality. In total, 25 dried Baim fish samples from each source were analyzed. E. coli was isolated from all dried Baim fish samples of Producer and Market source in all five months. But in case of control dried Baim fish sample, E. coli was found in the sample of the month of December and March. Salmonella was observed in the dried Baim fish sample of Producer in the month of March and April. Whilst, samples of Market source were found Salmonella positive in the month of December, March and April. However, all dried Baim samples of control was found free from Salmonella contamination (Table 7).

All the dried Baim fishes samples from Producer (Lamagaji) and Retail Market (Bandar Bazar) were found contaminated by E. coli. $80 \%$ dried Baim fishes sample of Market were found Salmonella and 60\% dried Baim fishes sample Producer were observed contaminated by Salmonella. However, control samples were recorded free from Salmonella (Table 7).

\section{Identification of fungal species}

\section{Aspergillus fumigatus}

For the A. fumigatus the colony have a diameter of $2-3 \mathrm{~cm}$ in 5 days. The flat colonies were white at first, whitish green as conidia began to mature, especially near the center of the colony.

\section{Identification of Fuserium proliferatum}

Fuserium proliferatum - Cultural character-Observe-Wooly, Cotton candy like and white and reserve - pink. Microscopic Character-Branched conidia located with conidiophores.

\section{Identification of Rhizopus stolonifer}

Rhizopus stolonifer - Cultural character-Observe-Colony is white initially then turns grey to yellowish brown in time and reserveWhite to pale. Microscopic Character - non separate or densely separate broad hypae, sporangiophores, rhizoids (root like hypae), sporangia and sporangiospores are exposed.

Percentage distribution of different fungal species in dried Baim fishes

Of the total 75 dried Baim fish sample resolved for the presence of fungal agents, 48 samples are positive for one or more fungal species. Fungal isolated were found 25 in retailer market, 15 in producer, 8 in control sample (Table 8 ).

Of the fungal agents diversed from Retail market sample, Aspergillus sp. 25 (100\%) from total sample 25, has the higher reccurrence, producer sample Aspergillus sp. 12 (48\%) from total sample 25, and control sample Aspergillus sp. 7 (21\%) from total sample 25 (Table 8).

Table 6. Biochemical characteristics of Salmonella on different test.

\begin{tabular}{|c|c|c|c|c|c|c|c|c|}
\hline \multirow{2}{*}{ Indole } & \multirow{2}{*}{ MR } & \multirow{2}{*}{ VP } & \multirow{2}{*}{ Catalase test } & \multirow{2}{*}{ TSI Slant } & \multicolumn{4}{|c|}{ Sugar fermentation test } \\
\hline & & & & & Dextrose & Maltose & Mannitol & Lactose \\
\hline -ve & +ve & -ve & +ve with gas bubble & Red & + ve & + ve & + ve & -ve \\
\hline
\end{tabular}

Table 7. Summary of isolation of E. coli and Salmonella from dried Baim.

\begin{tabular}{|c|c|c|c|}
\hline \multirow{2}{*}{ Sample } & & \multicolumn{2}{|c|}{ Isolated bacteria } \\
\hline & & E. coli & Salmonella \\
\hline \multirow{3}{*}{ Retailer market (Bandar Bazar) } & No of sample analysed & 25 & 25 \\
\hline & No of positive sample & 25 & 20 \\
\hline & $\%$ of positive sample & 100 & 80 \\
\hline \multirow{3}{*}{ Producer (Lamagaji) } & No of sample analysed & 25 & 25 \\
\hline & No of positive sample & 25 & 15 \\
\hline & $\%$ of positive sample & 100 & 60 \\
\hline \multirow{3}{*}{ Control } & No of sample analysed & 25 & 25 \\
\hline & No of positive sample & 0 & 0 \\
\hline & $\%$ of positive sample & 0 & 0 \\
\hline \multirow{3}{*}{ Total } & No of sample analysed & 75 & 75 \\
\hline & No of positive sample & 50 & 35 \\
\hline & $\%$ of positive sample & 66.67 & 46.67 \\
\hline
\end{tabular}


Of the fungal agents isolated from Retail market sample, Fuserium sp. 19 (76\%) from total sample 25, has the higher frequency of occurrence, producer sample Fuserium sp. 10(40\%) from total sample 25 , and control sample Fuserium sp. 4(16\%) from total sample 25 (Table 8).

Of the fungal agents isolated from Retail market sample, of Rhizopus sp. 17 (68\%) from total sample 25, has the higher frequency of occurrence, producer sample of Rhizopus sp. 5 (20\%) from total sample 25 , and control sample of Rhizopus sp. 4 (16\%) from total sample 25 (Table 8).

Now a day, food quality and safety is one of the major troubles in the whole world; that forced many researchers to discuss methods of addressing consumer concerns with various aspects of food safety and quality (Nielsen et al., 2009). So, our current study was conducted to perform quantitative and qualitative analysis of microbes in dried Baim.

Mean total bacterial load of the dried fishes of Producer, Market and Control were observed $6.20 \pm 0.72 \times 10^{5}, 9.64 \pm 1.58 \times 10^{5}$ and $1.61 \pm 1.06 \times 10^{5} \mathrm{cfu} / \mathrm{g}$, respectively. It has been reported that TPC in sun-dried baim fish samples ranged from $3.7 \times 10^{3}$ ( 0 day) to $3.3 \times 10^{6} \mathrm{cfu} / \mathrm{g}$ (6 month) respectively (Bilgin et al., 2008). Hasan et al. (2006) found that the bacterial load of traditional, rotary and solar tunnel dried products were in the range of $1.43 \times 10^{8}$ to $2.89 \times 10^{8} \mathrm{cfu} / \mathrm{g}, 1.91 \times 10^{8}$ to $2.84 \times 10^{8} \mathrm{cfu} / \mathrm{g}$ and $1.95 \times 10^{8}$ to $2.59 \times 10^{8} \mathrm{cfu} / \mathrm{g}$, respectively. With increase in duration of storage, total viable counts (TVC) of dried fish samples were increased due to growth and multiplication of the microbes (Bilgin et al., 2008). The bacterial count in dried fishes was less than $10^{7} \mathrm{cfu} / \mathrm{g}$ (Sanjeev, 1997). Lilabathi et al. (1999) reported the there is a direct relationship between the total microbial count and water content of the dried fish sample. Patterson and Ranjitha (2009) enumerated that total plate count (TPC) seemed to be high in the commercially dried fishes than the experimentally dried fishes. Our finding is similar with the results reported by Majumdar et al. (2017) Rasul et al. (2018) and Majumdar et al. (2018). Significantly $(P<0.05)$ the highest and the lowest bacterial count were observed in the month of April and January, respectively. This variation in TPC might occur because of the differences in moisture and temperature in different months. In every circumstance, maximum TPC was observed in market sample and minimum TPC was observed in control sample. ICMSF (ICMSF, 1986) suggested that quality levels are raised on the plate counts with representative sample unit less than $5 \times 10^{5} \mathrm{cfu} / \mathrm{g}$ are good quality between $5 \times 10^{5}$ $10^{7} \mathrm{cfu} / \mathrm{g}$ marginally accepted quality and plate count at or above $10^{7}$ are considered unacceptable in quality and safety.
The quality of dry fishes was adversely influenced by occurrence of fungi (FDA, 1982). Mean fungal load of dried Baim fishes of Producer, Market and Control were estimated $3.77 \pm 0.81 \times 10^{3}, \quad 4.65 \pm 1.08 \times 10^{3}$ and $1.78 \pm 0.64 \times 10^{3} \mathrm{cfu} / \mathrm{g}$, respectively. It has been reported that TFC of dried punti were varied from $1.15 \pm 0.10 \times 10^{2} \mathrm{cfu} / \mathrm{g}$ to $7.43 \pm 0.25 \times 10^{4} \mathrm{cfu} / \mathrm{g}$ in producer, retail market and control sample (Hossain et al., 2016). Sulieman and Mustafa (Sulieman and Mustafa, 2012) estimated the fungal load of dried fishes from Eldeim area (Central Sudan) in the range of $1.5 \times 10^{2}-5.3 \times 10^{4} \mathrm{cfu} / \mathrm{g}$. Saritha et al. (2012) reported that the range of TFC were $1.3 \times 10^{4}-2.2 \times 10^{4} \mathrm{cfu} / \mathrm{g}$ in dried fishes of Cuddalore district, India.

Seasonal variation in water content of dried fish products could be depend on the result of different drying time, environmental changes and level and type of salt used for curing (Anihouvi et al., 2006). In our study, in all the dried fish seasonal variation in the fungal population was observed. Patterson and Ranjitha (2009) calculated TFC from commercially and experimentally dried fishes exposed that total fungal count seemed to be high in the commercially dried fishes than the experimentally dried fishes. Overall, significantly $(P<0.05)$ the highest and the lowest fungal counts were observed in the month of March and January, respectively. No such significant differences were found between the fungal loads of the month of December, March and April. This observation seems suggest that the variation of TFC in different months because of the differences in moisture and temperature level. Significantly the highest TFC were observed in the dried Baim of Market.

Indicator bacteria i.e. E. coli has been isolated and identified from dried Baim of different sources. The colony characteristics of $E$. coli in this study, on EMB agar found smooth, circular, black centred colonies with metallic sheen, on NA found smooth, circular and white colored colonies, also found slight growth of pink to red colonies on SS agar and smooth pinkish colonies on MCA which responds well with observations of several other authors (Sharada et al., 2009; Buxton and Fraser, 1977). In Gram's staining, the morphology of the isolated bacteria developed gram negative short rod arranged in single or paired and in hanging drop slide tests it was found motile which were parallel to the reports of (Sharada et al., 2009; Buxton and Fraser 1977; Merchant and Packer, 1967). The isolates also stated positive reaction in MR test and Indole test but negative reaction in VP test and in TSI slant test it was found yellow slant and butt with gas but no $\mathrm{H}_{2} \mathrm{~S}$ production which were similar to the observations of (Buxton and Fraser, 1977).

Table 8. Percentage distribution of different fungal species in dried Baim fishes.

\begin{tabular}{lccccccc}
\hline \multirow{2}{*}{ Sample source } & \multirow{2}{*}{ Total sample } & \multicolumn{2}{c}{ Aspergillus sp. } & \multicolumn{2}{c}{ Fuserium sp. } & \multicolumn{2}{c}{ Rhizopus sp. } \\
\cline { 3 - 7 } & & Presence & Percentage & Presence & Percentage & Presence & Percentage \\
\hline Market & 25 & 25 & $100 \%$ & 19 & $76 \%$ & 17 & $68 \%$ \\
Producer & 25 & 12 & $48 \%$ & 10 & $40 \%$ & 5 & $20 \%$ \\
Control & 25 & 7 & $21 \%$ & 4 & $16 \%$ & 4 & $16 \%$ \\
Total & 75 & 44 & $58.67 \%$ & 33 & $44 \%$ & 26 & $26 \%$ \\
\hline
\end{tabular}


In our present study, 75 samples of dried Baim fishes were analyzed to isolate and identify E. coli and 50 samples were found contaminated with E. coli. All 25 samples (100\%) of Producer and Retail Market were recorded E. coli. E. coli is endangered because the production of histamine in the dried fishes (Logesh et al., 2012). The presence of faecal coliform bacteria, including E.coli in most of the samples examined indicates poor hygiene and sanitary condition. This finding verifies with the study of (Feng et al., 2014).

Cultural characteristics of Salmonella were recorded. In Gram's staining, the morphological characteristics of the isolated Salmonella exhibited Gram negative, small rod shaped, single or paired in arrangement under microscope which was approved by work of other researchers (Gene, 2002; Jones et al., 1997 and Freeman, 1985). Besides, in sugar fermentation test, all the Salmonella isolates fermented dextrose, maltose and mannitol and produce acid and gas but did not ferment sucrose and lactose which is similar to the report of (Buxton and Fraser, 1977). Again, all the Salmonella isolates were positive to methyl red test and negative to indole and VP test and in TSI slant test, it was found but remained yellow and slant converted to pink color (Merchant and Packer, 1967). These results are related to the results referred by (Rahman, 1977); Cherry et al., 2004). A number of 75 ( 25 samples from each source) dried Baim samples were analyzed to isolate and identify Salmonella. Overall, $46.67 \%$ samples of dried Baim were found contaminated by Salmonella. 80\%, 60\% samples of Producer and Retail Market were recorded Salmonella, respectively. No Salmonella was found in Control samples of dried Baim.

Different types of fungal species were also isolated in the dried Baim samples. Dried samples from Market was $100 \%$ contaminated with fungi, Producer sample was $62 \%$ contaminated and Control sample was $32 \%$ contaminated with fungi. This fungal community may be due to the variation in the chemical and nutritional composition of the fish species and for that reason, different moulds react differently in various fish (Reed et al. 1967; Fafioye et al., 2002). The various organisms were determined under the light microscope showed Aspergillus flavus as yellowish green and A. niger as dark in colour. However, these two Aspergillus species are microscopically alike. These are the most common fungi invading dried fish species in the study area. Similar results were observed by Doe (Doe, 1983) (AlfredOckiya and Akeodi, 1998). However, the fungus Aspergillus flavus is mainly accountable for the production of aflatoxin and it also causes food borne intoxication which leads to serious health hazards of consumers (Kumar et al., 2017). So safety procedures should be taken to reduce the contaminations and insect infestations of dried fish.

\section{Conclusion}

The microbiological condition in dried Baim was poor in our study areas which may be caused by the improper and unhygienic handling, lack of sanitation of labours, poor processing, improper storage and inadequate packaging of the products. Therefore, control measures such as ensuring scientific, developed and hygienic fish drying method (e.g. use of good quality raw material, good quality salt, hygienic handling practices, potable water, good quality packaging material), training of the fisher folks and increasing the awareness of mass people about food safety should be taken.

\section{ACKNOWLEDGEMENTS}

The authors wish to thank Mofizul Haque, the Department of Microbiology and Immunology of SAU, Sylhet for helping with the microbiological analysis. The work was financially supported by the Ministry of Science and Technology of Bangladesh.

Conflicts of Interest: The authors declare that they have no conflict of interest.

Open Access: This is an open access article distributed under the terms of the Creative Commons Attribution 4.0 License, which permits unrestricted use, distribution, and reproduction in any medium, provided the original author(s) if the sources are credited.

\section{REFERENCES}

Alfred, O.J.F. and Akeodi, J. (1998). Comparative study of fungal infestation of three traditionally smoked- dried fresh water fishes in rivers State. Journal of Aquaculture Science, 13: 4143.

Anihouvi, V.B., Ayernorgs, J.D., Hounhouigan, $H$. and Sakyi-Dawson, E. (2006). Quality characteristics of Lanhouin: A traditionally processed fermented fish product in the Republic of Benin. African Journal of food Agriculture Nutrition and Development, 6: 1-6.

AOAC. (1998). Bacteriological analytical manual, 8th edition, Association of official analytical chemists, Washington, DC.

APHA. (1992) Compendium of methods for the microbiological Examination of foods, $3^{\text {rd }}$ edition, C. Vander dent, and Splittstoesser, D, (Editors), APHA, Washington DC 2: pp 1264.

Archer, J., Jervis, E.T., Bird, J. and Gaze, J.E. (1998). Heat resistance of Salmonella weltevreden in low-moisture environments. Journal of Food Protection, 61: 969-973.

Bala, B.K. and Mondol, M.R.A. (2001). Experimental investigation on solar drying of fish using solar tunnel dryer. Drying Technology, 19(2): 427-436.

Bellagha, S., Amami, E., Farhat, A. and Kechaou, N. (2002). Drying kinetics and characteristic drying curve of lightly salted Sardine (Sardinella aurita). Drying Technology, 20 (7): 1527-1538.

Beuchat, L.R. and Mann, D.A. (2011). Inactivation of Salmonella on pecan nutmeats by hot air treatment and oil roasting. Journal of Food Protection, 74 (9): 1441-1450.

Beuchat, L.R., Komitopoulou, E., Beckers, H., Betts, R.P., Bourdichon, F., Fanning, S. and Kuile, B.H.T. (2013). Low-water activity foods: increased concern as vehicles of 
foodborne pathogens. Journal of Food Protection, 76(1): 150 $-172$.

Bilgin, F., Ünlüsayin, M., Izci, L. and Günlü, A. (2008). The determination of the shelf life and some nutritional components of Gilthead Seabream (Sparus aurata L. 1758) after cold and hot Smoking. Turkish Journal of Veterinary and Animal Science, 32(1): 49-56.

Buxton, A. and Fraser, G. (1977) Animal microbiology. Blackwell scientific publications, Oxford, London, Edinburg, Melbourne, 1: 85-110.

Cherry, B.A., Burns, G.S., Johnson and Dumas, N. (2004). Salmonella typhimurium outbreak associated with veterinary clinic. Emerging Infectious Diseases Journal, 10: 2249- 2252.

Cousin, M.A., Riley, R.T. and Pestka, J.J. (2005). Foodborne mycotoxins: Chemistry, biology, and toxicology. In: Fratamico PM, Bhunia AK and Smith JL (Editors), Foodborne pathogens: Microbiology and molecular biology. Norfolk, UK: Caister Academic Press. 163-226 pp.

Deng, Y., Ryu, J.H. and Beuchat, L.R. (1998). Influence of temperature and $\mathrm{pH}$ on survival of Escherichia coli O157:H7 and growth in reconstituted infant rice cereal. International Journal of Food Microbiology, 45(3):173-184.

Doe, P.E. (1983) Spoilage of dried fish: The need for more data on water activity and temperature effects on spoilage organism. FAO Fisheries Report, Rome, 27(9):126-129.

Duan, Z.H., Zhang, M. and Tang, J. (2004). Thin layer hot-air drying of bighead carp. Fisheries Science, 23 (3): 29-32.

Fafioye, O.O., Efuntoye, M.O. and Osho, A. (2002). Studies on the fungal infestation of five traditionally smoke-dried fresh water fish in Efuntoye Ago-Iwoye, Nigeria. Mycopathologia, 9: 154-177.

FAO. (2018). The State of World Fisheries and Aquaculture 2018 - Meeting the sustainable development goals. Rome. Licence: CC BY-NC-SA 3.0 IGO.

FDA BAM .(2007). Bacteriological analytical manual, Salmonella. $8^{\text {th }}$ edition. Food and Drug Administration, USA.

Feng, P., Weagent, S.D. and Grant, M.A., Bacteriological analytical manual 002. Online. www.lib.ncsu.edu/pubweb/www/ ETDdb/web_root/collection/available/etd-04102005-

213953/unrestricted/etd.pdf.

Food and Drug Administration (FDA). (1982), Reference manual to codes of practices for fish and fishery products, FAO. Rome. 152 pp.

Freeman, B.A. (1985). Burrows textbook of microbiology. 22"d edition W. B. Saunders Company, Philadelphia, London, Toronto, Mexici City, Rio de Janerio, Sydney, Tokyo. pp. 464-472.

FRSS. (2016). Fisheries resources survey system (FRSS), fisheries statistical report of Bangladesh (vol. 32, pp. 1e57). Bangladesh: Department of Fisheries.

Gene, O. (2002). The isolation, identification and serotyping of Salmonella isolated from domestic poultry in Kars district. Kafkas Univarsikesi Veteriner Fakultesi, Dergisi. 8: 23-30.

Hasan, M.M., Rasul, M.G., Ferdausi, H.J., Trina, B.D., Sayeed, A.,
Shah, A.K.M.A. and Bapary, M.A.J. (2016). Comparison of organoleptic and chemical characteristics of some traditional and improved dried fish products. Research journal of Animal, Veterinary and Fishery Sciences, 4(2): 1-6.

Hasan, M.M., Shikha, F.H., Hossain, M.I., Kamal, M., Islam, M.N. and Wahab, M.A. (2006). Quality assessments of traditional, rotary and solar tunnel dried small indigenous fish products. Bangladesh. Journal of Fisheries Research, 10(1): 73-84.

Hossain, K.M. (2002). Characterization of bacteria isolated from diarrhoeic calves. MS Thesis, submitted to the Department of Microbiology and Hygiene, Faculty of Veterinary Science, BAU, Mymensingh, pp. 45-53.

Hossain, M.A., Sayeed, M.A., Kabir, L.M., Sumon, T.A., Himu, S.D. and Sumon, M.A.A. (2016). Determination of microbiological quality of dried jat punti (Puntius sophore) collected from Sylhet district, Bangladesh. International Journal of Natural and Social Sciences, 3(3): 72-79.

Hyun, J.E., Kim, J.H., Choi, Y.S., Kim, E.M., Kim, C. and Lee, S.Y. (2018). Evaluation of microbial quality of dried foods stored at different relative humidity and temperature, and effect of packaging methods. Journal of Food Safety, 38(2): e12433.

ICMSF, International Commission for Microbiological Specification for Foods (1998). Micro-organisms in Foods 6. Blackie Academic and Professional, London.

ICMSF, International Commission on Microbiological Specifications for Foods (1986). Microorganisms in foods sampling for microbiological analysis: Principles and specific applications. 2nd edition. University Toronto Press, Canada.

Jones, T.C., Hunt, R.D. and King, N.W. (1997). Veterinary Pathology. 6th edition. Williams and Wilkins Co, Baltimore, USA.

Kumar, P., Mahato, D.K., Kamle, M., Mohanta, T.K. and Kang, S.G. (2017). Aflatoxins: A Global Concern for Food Safety, Human Health and Their Management. Front. Microbiol. 7: 2170.

Lilabati, H., Vishwanath, W. and Singh, M. (1999). Changes in bacterial and fungal quality during storage, Esomus danricus of Manipur. Fishery Technology, 36: 36 - 39.

Logesh, A.R., Pravinkumar, M., Raffi, S.M. and Kalaiselvam, M. (2012). An Investigation on microbial screening on salt dried marine fishes. Journal of Food Resource Science, 1:15 21.

Majumdar, B.C., Afrin, F., Rasul, M.G., Khan, M. and Shah, A.K.M.A. (2017). Comparative study of physico-chemical, microbiological and sensory aspects of some sun dried fishes in Bangladesh. Brazilian Journal of Biological Science, 4 (8): 323-331.

Majumdar, B.C., Afrin, F., Rasul, M.G., Shaha, D.C. and Shah, A.A. (2018). Changes in Physicochemical, Microbiological, and Sensory Properties of Sun-Dried Mystus vittatus During Storage at Ambient Temperature. Fishes, 3(3): 32.

Mazid, M.A. and Kamal, M. (2005). Development of low cost solar dryer for the production of improved quality dried fish. Final Report. BFRI, Marine Fisheries \& Technology 
Station and Bangladesh Agricultural University, Mymensingh. pp. 65.

Merchant, I.A. and Packer, R.A. (1967). Veterinary Bacteriology and Virology. 7th edition, The lowa University Press, Ames, lowa, USA, pp. 286-306.

Nielsen, H.B., Sonne, A.M, Grunert, K.G., Banati, D., Pallak Toth, A. and Lakner, Z. (2009). Consumer perception of the use of high-pressure processing and pulsed electric field technologies in food production. Appetite, 52:115-126.

Nowsad, A.K.M.A. (2007). Participatory training of trainers: A new approach applied in fish processing. Bangladesh Fisheries Research Forum, Dhaka, 328.

Patterson, J. and Ranjitha, G. (2009). Qualities of commercially and experimentally sun dried fin fish, Scomberoides tol. African Journal of Food Science, 3(10): 299-302.

Petrus, P.H. and Suprayitno, E. (2013). Physicochemical characteristics, sensory acceptability and microbial quality of WadiBetok a traditional fermented fish from South Kalimantan, Indonesia. International Food Research Journal, 20(2): 933-939.

Rahman, M.M. (1977). Isolation and identification of Salmonella and Escherichia coli from river water, pond water, tap water, tube well water and poultry feed. MS Thesis, Department of Microbiology and Hygiene, Bangladesh Agricultural University, Mymensingh-2202. pp. 75.

Rasul, M.G., Majumdar, B.C., Afrin, F., Bapary, M.A.J. and Shah, A.K.M.A. (2018). Biochemical, microbiological and sensory properties of dried Silver carp (Hypophthalmichthys molitrix) influenced by various drying methods. Fishes, 3(3): 25.

Reed, W., Burchard, J., Hopson, A.J., Jenness, J. and Yaro, L. (1967). Fish and fisheries of Northern Nigeria. Gaskiya Corporation, Zaria, Northern Nigeria, pp 226.
Rippon, J.W. (1998). Medical Mycology: the pathogenic fungi and the pathogenic actinomycetes. $3^{\text {rd }}$ edition. pp. 618-646.

Sanjeev, S. (1997). Studies on coagulase positive Staphylococcus and Vibrio parahaemolyticus in selected items of fish. Crustaceans and fishery products, Cochin University of science and technology, Cochin, India.

Saritha, K., Immaculate Jayasantha, K., Aiyamperumal, V. and Patterson, J. (2012). Microbial and Biochemical Qualities of Salted and Sun Dried Sea Foods of Cuddalore, Southeast Coast of India. International Journal of Microbiological Research, 3 (2): 138 -143.

Sen, B.R., Sabur, S.A., Islam, T. and Alam, K. (2015). Forecasting the quantity of shrimp and dry fish export from Bangladesh. Journal of Economics and Sustainable Development, 6: 7.

Sharada, R.S.W., Ruban, and Thiyageeswaran, M. (2009). Antibiotic resistance pattern of Escherichia coli isolated from poultry In Bangalore. International Journal of Microbiology, 7(1): 65-75.

Sulieman, A.M.E. and Mustafa, W.A. (2012). Quality characteristics of dried fish obtained from Eldeim Area, Central Sudan. International Journal of Food Science and Nutrition Engineering, 2(1): 1-6.

Sultana, N., Siddique, M.P., Farhana, Z., Dina, M.A. and Uddin, M.I. (2010). Isolation and identification of bacteria from dried fishes collected from different areas of Bangladesh. International Journal Bioresource Stress Management, 2(9): 01-05.

Yamagata, M. (1992). Fungi (mould and yeast) plate count. In: Miwa K., Ji L.S. (editors) Laboratory Manual on Analytical Methods and Procedures for Fish and Fish Products, $2^{\text {nd }}$ edition Marine Fisheries Research Department, Southeast Asian Fisheries Development Center in collaboration with Japan International Cooperation Agency. 